Print ISSN: 2288-4637 / Online ISSN 2288-4645

doi:10.13106/jafeb.2020.vol7.no11.001

\title{
Corporate Social Responsibility and Unsecured Debt: Evidence from China*
}

\author{
Xia CHEN ${ }^{1}$, Zhe MA², Jiayu SHI ${ }^{3}$, Bingyan TU ${ }^{4}$, Songtao XU ${ }^{5}$
}

Received: August 01, 2020 Revised: September 20, 2020 Accepted: October 05, 2020

\begin{abstract}
This study aims to investigate whether Corporate Social Responsibility (CSR) performance can help companies gain more bank unsecured loans. Additionally, this study analyzes the moderating effect of firm size and industry characteristics. Data was collected through the case of companies listed on the Shanghai Stock Exchange or the Shenzhen Stock Exchange in China between 2009 and 2018 with 5373 firmyear observations. The results of multivariable regression analysis show that good CSR performance exhibits a strong positive impact on unsecured debt, including short-term, long-term, and total unsecured debt, which indicates that corporate with good CSR performance can borrow more unsecured debt. further research shows that this effect is more pronounced for small enterprises and firms operating in heavy-polluting industries. Additionally, research on the impact mechanism finds that good CSR performance can help mitigate information asymmetry between borrower and lender, reduce moral hazard of borrower, and obtain support from key stakeholders, and therefore reduces the risk of default. The findings of this study suggest that firms with good CSR performance exhibit a preference for unsecured debt, but decline to provide collateral for debt. Overall, we emphasize and illustrate the important role of corporate CSR in bank credit financing.
\end{abstract}

Keywords: Corporate Social Responsibility, Unsecured Debt, Information Asymmetry, Moral Hazard, Default Risk

JEL Classification Code: G21, G30, M14

\section{Introduction}

As a key stakeholder, banks are the main provider of corporate external financing. Therefore, determining whether banks can be in favor of borrowers' CSR performance is

\footnotetext{
*Acknowledgements:

This research was funded by the Humanities and Social Sciences Research Projects of Universities in Jiangxi Province [JC17124].

${ }^{1}$ First Author. [1] College of Business Administration, University of the Cordilleras, Philippines [2] Lecturer, School of Management, Jiujiang University, China. Email: cxwhut@163.com

${ }^{2}$ Lecturer, School of Management, Jiujiang University, China.

Email: mazhe@jju.edu.cn

${ }^{3}$ Lecturer, School of Management, Jiujiang University, China.

Email: shijiayu@jju.edu.cn

${ }^{4}$ Associate Professor, Jiujiang Vocational University, China.

Email: bingyantu@163.com

${ }^{5}$ Corresponding Author. Associate Professor, School of Management, Jiujiang University, China [Postal Address: 551 East Qianjin Road, Jiujiang City, Jiangxi Province, 332005, China]

Email: songter@jju.edu.cn ; songter@126.com

(c) Copyright: The Author(s)

This is an Open Access article distributed under the terms of the Creative Commons Attribution Non-Commercial License (https://creativecommons.org/licenses/by-nc/4.0/) which permits unrestricted non-commercial use, distribution, and reproduction in any medium, provided the original work is properly cited.
}

very important in supporting CSR initiatives. In fact, the Equator Principles, launched in 2003, has been adopted voluntarily by many financial institutions across the world, to determine, assess, and manage environmental and social risks in project finance. Current literature focuses on the relation between borrowers' CSR performance and bank loan decisions, including debt spreads (Goss \& Roberts, 2011) and maturity (Benlemlih, 2017), and also extends the decisions of banks to bond investor and relevant agency, such as credit ratings (Attig, El Ghoul, Guedhami, \& Suh, 2013) and bond yield spreads (Dbouk, Jin, Wang, \& Wang, 2018). However, researchers have not considered the different types of bank debt, with their different properties and risks for borrowers and lenders. Accordingly, we fill this gap in scholarly understanding by examining the impact of CSR performance on unsecured debt. Due to reliance on the creditworthiness of borrowers without any collateral, banks set higher requirements for unsecured loans to control credit risk. Rauh and Sufi (2010) find that banks are favorably predisposed to high-quality firms when issuing unsecured loans. Additionally, to maintain financial and operational flexibility, firms are reluctant to issue secured debt (Efraim Benmelech, Kumar, \& Rajan, 2020). Therefore, it is important to analyze debt heterogeneity in bank debt studies, and especially the use of unsecured debt. 
We use Chinese listed firms, whose CSR performance was ranked by Rankins Global during 2009-2018, to evaluate the effect of borrowers' CSR performance on unsecured debt. The results show that firms with good CSR performance can borrow more unsecured debt than ones with lower CSR performance. We also find that the impact of CSR performance on unsecured debt is more important in small enterprises and firms operating in heavy-polluting industries. Additionally, we explore three plausible channels through which good CSR performance helps borrowers gain more unsecured bank loans. First, good CSR performance is associated with improvement in information transparency, evidenced by low error of analyst forecast. Second, the fulfillment of CSR plays a vital role in reducing moral hazard, as represented by the borrower's annual violations. Finally, CSR helps to decline in default risk, as reflected in government support, institutional investor, and supplier respectively.

Our study contributes to current literature in several ways. First, this study is the first such study to examine the role of CSR performance in unsecured debt. Several studies have explored the relation between CSR performance and banks' loan decisions (Benlemlih, 2017; Goss \& Roberts, 2011), but did not consider the differences between various types of bank debt. Ceteris paribus, firms that pledge collateral find it easier to borrow bank secured debt (E. Benmelech \& Bergman, 2009). This paper sets unsecured debt as the research object and overrides the influence of the borrower's collateral. Therefore, our conclusions are more robust and better reflect the role of CSR on banks' loan decisions. Second, our study advances scholarly knowledge by adding new determinants of unsecured debt, whereas previous literature on unsecured debt mainly focuses on individual or household borrowers and paid little attention to corporate finance (Degryse, Karapetyan, \& Karmakar, 2018). Our study approaches the issue from the perspective of a firm's CSR performance and its effect on unsecured debt. Third, this paper contributes to the debate on the borrowers' preference for different types of bank debt. Chan and Kanatas (1985) argue that secured debt enables high-quality firms to signal their creditworthiness by providing collateral, whereas Benmelech et al. (2020) found that borrowers do not want to compromise their financial and operational flexibility by offering collateral, and prefer unsecured debt instead. If good CSR performance can help improve information transparency, mitigate moral hazard and default risk, it is very interesting to observe whether good CSR performance can substitute collateral for signaling a firm's creditworthiness. Furthermore, this study helps us understand the preference of different types of bank debt for low-risk borrowers.

\section{Literature Review and Hypothesis}

\subsection{Literature Review}

Two alternative views may explain the relationship between CSR performance and debt. On the one hand, the risk mitigation view posits that CSR engagement improves a firm's risk management and hence mitigates idiosyncratic risk (Albuquerque, Koskinen, \& Zhang, 2019; Jo \& Na, 2012), which induce lenders to offer favorable loan terms (Goss \& Roberts, 2011) . On the other hand, the agency conflict view argues that managers overinvest in CSR and can gain private benefits at the expense of shareholders; consequently, the benefits of allocating resources to CSR activities may not justify the cost (Barnea \& Rubin, 2010) and CSR activites carry some some financial risks for an immediate short-term (Lee, 2020). Therefore, lenders ignore the influence of a borrower's CSR strengths (Dbouk et al., 2018) . However, due to the asymmetric payoff with respect to firm net assets, lenders are more interested in the downside risk of their debt investments (W. X. Ge, Kim, \& Song, 2012). Oikonomou, Brooks, and Pavelin (2014) and W. Ge and Liu (2015) also found that lenders are more concerned over the positive effects of CSR rather than the negative effects.

Overall, current literature argues that good CSR performance mitigates the borrower's idiosyncratic risk and helps them ensure favorable loan terms, but scholars tend not to examine the mechanisms empirically and ignore the heterogeneity of bank debts. Additionally, Benmelech et al. (2020) document a steady decline in the proportion of secured debt issued during the twentieth century. One of the reasons is that borrowers do not want to lose financial and operational flexibility for collateral. Instead, collateral is given on a contingent basis when a borrower approaches a state of distress. It is interesting to observe whether firms with good CSR performance can borrow more unsecured debt. Hence, we advance current literature in the following ways. First, we focus the effect of borrower's CSR performance on unsecured debt. Second, we explore the three channels through which CSR can mitigate the risk of banks' unsecured loans. Finally, we compare the borrower's preference between unsecured debt and secured debt.

\subsection{Determinants of Unsecured Debt}

To control adverse selection, reduce the borrower's moral hazard, and default risk, banks usually require borrowers to reduce loan risk by pledging collateral (Gonas, Highfield, \& Mullineaux, 2004). The problem of adverse selection stems from information asymmetry. The more serious the information asymmetry, the more likely the borrower will be asked to pledge collateral as a method of loan screening and controlling default risk (Manove, Padilla, \& Pagano, 2001). Moral hazard also derives from information asymmetry. The intuitive remedies to the problem involve investing resources into monitoring the agent's actions and using more information in contract design (Holmstrom, 1979). Moreover, collateral is more likely to be posted with borrowers of high moral hazard by lenders (Arnoud, Thakor, \& Udell, 1991). 
In terms of default risk, borrowers with obvious default risk are more likely to provide collateral, which suggests that banks are more likely to control default risk with the use of collateral for high-risk borrowers (Berger, Frame, \& Ioannidou, 2016; Brickson, 2007).

Unsecured debt depends on the creditworthiness of borrowers without any collateral. The lender will receive no payment in the event of unsecured debt default. Therefore, banks will have higher requirements for unsecured loans in terms of controlling loan risk. Theoretical works and empirical studies also show that high credit-quality firms rely exclusively on unsecured loans, whereas low creditquality firms rely more on secured loans (Benmelech et al., 2020; Luk \& Zheng, 2018; Rauh \& Sufi, 2010).

\subsection{The Impact of CSR on Unsecured Debt}

The purpose of CSR is to satisfy the requirements of stakeholders. Only by communicating with external stakeholders can a firm effectively determine their demands regarding value, attitude, and behavior (Pedersen, 2006). Therefore, the activation of CSR bears external communication effects (Verrecchia, 2001). Previous literature establishes that firms with good CSR performance can provide higher quality of accounting information than those with poor CSR performance (Kim, Park, \& Wier, 2012). Yoon and Lee (2019) also found that a negative relationship between CSR performance and the dispersion of analyst forecasts when excluding chaebol affiliates from the sample. Above all, firms with good CSR performance can reduce information asymmetry between management and external stakeholders, which helps banks avoid adverse selection in the decision-making process before issuing a loan.

Regarding reputation, firms will attempt to suppress their opportunistic behaviors. Therefore, reputation plays a vital role in constraining borrowers' moral hazard after they successfully obtain loans (Diamond, 1991). The fulfillment of CSR helps firms establish relationships of mutual trust with external stakeholders and to enhance their reputation (Cahan, Chen, Chen, \& Nguyen, 2015). In addition, CSR can reduce information asymmetry, which is beneficial for lenders and their review of a borrower's behavior. Hence, good CSR performance will alleviate a borrower's moral hazard.

As a strategic orientation, CSR can service the interests of external stakeholders and build social capital based on relationships of mutual trust. For this reason, CSR plays an important role in securing the stakeholder's support (Russo \& Perrini, 2010). Essentially, firms with good CSR performance are more likely to receive support from stakeholders during periods of financial crisis (Lins, Servaes, \& Tamayo, 2019; Lins, Servaes, \& Tamayo, 2017). Additionally, Nguyen,
Pham, Nguyen, and Dinh (2020) also found that firms with higher level of social responsibility disclosures performance can rapidly reduce their risk of bankruptcy.

Combined with the analysis above, companies with good CSR performance can reduce the banks' credit risk in three ways: (1) Adverse selection. With reduced information asymmetry achieved by good CSR performance, the bank's risk of adverse selection in credit decision declines. In addition, the improved reputation that CSR brings can be used as a screening basis for identifying high-qualified borrowers during the decision-making process; (2) Moral hazard. The reputation brought by CSR can inhibit the ex-post moral hazard of the borrower. The decrease of information asymmetry is also conducive to bank's ex-post supervision; (3) Default risk. Good CSR performance secures support from stakeholders and helps reduce the default risk. Therefore, one can argue that firms with good CSR performance are more likely to obtain unsecured loans from banks. Accordingly, we state our first hypothesis as follows:

H1: The better the firm's CSR performance, the more likely it is that the firm borrows more unsecured debt.

Previous research shows that larger firms are likely to have more trading transactions, receive more attention from analysts and get more media coverage (Diamond \& Verrecchia, 1991), and thus have more information transparency than smaller firms (Bushman, Piotroski, \& Smith, 2004). Furthermore, smaller firms are more vulnerable to economic fluctuation and have higher operating and financial risk (Fort, Haltiwanger, Jarmin, \& Miranda, 2013). For these reasons, banks tend to discriminate against small firms (Almeida, Campello, \& Weisbach, 2004; Collins \& Baker, 2005).

Brown and Hillegeist (2007) found that the benefit of reducing information asymmetry through incremental information disclosure will be greater for firms with higher information asymmetry. Within a context of credit discrimination against small firms, more information asymmetry occurs between small firms and banks. Hence, the activities of CSR can be an important means for the management of small firms to communicate and gain attention from banks. In contrast, due to the emphasis on lending relationship and multiple information channels, banks have more information about larger firms. The signal of CSR activities will have fewer effects on banks' information acquisition.

As discussed above, CSR can also mitigate the borrower's default risk by gaining the support of stakeholders. Because of higher operating and financial risks, the help of stakeholders will be more valuable for small firms in their effort to decrease default risk. Thus, we form the following hypothesis: 
H2: Ceteris paribus, the effect of good CSR performance on borrowing unsecured debt is more pronounced for small firms.

Heavy-polluting industries are subject to stricter regulations in comparison to other industries. Firms operating in heavy-polluting industries endure more legitimacy pressure and scrutiny from the government, the general public, as well as from investors and other stakeholders. Failure to abide by environmental regulation will put firms in heavy-polluting industries at great operational risk (Cai, Cui, \& Jo, 2016), even in danger of business termination (Pellegrino \& Lodhia, 2012). Engaging in CSR activities, especially in environmental governance, can enhance the conformity of firms in heavy-polluting industries more effectively than those operating in non-heavy-polluting industries. The higher level of social acceptance a firm gains, the lesser default risk it suffers (Kölbel \& Busch, 2020). Hence, we state the following hypothesis:

H3: Ceteris paribus, the effect of good CSR performance on borrowing unsecured debt is more pronounced for firms in heavy-polluting industries.

\section{Research Design}

\subsection{Sample Selection}

Rankins Global has ranked CSR performance of listed companies in China that have disclosed CSR reports since 2008. With regard to tackling endogenous problems, the regression model must lag CSR performance variable by one-period. Therefore, the initial sample comprises listed companies that have been ranked by Rankins Global between 2009 and 2018. We excluded financial companies and those which have received special treatment. We also deducted firm-year observations with missing variables and the first year of IPO. After these restrictions, 5,373 firmyear observations comprise our final sample. To control the influence of extreme values, quantiles of continuous variables below $1 \%$ or above $99 \%$ are minimized.

\subsection{Baseline Regression Model}

In order to examine the impact of CSR performance on unsecured debt, we construct the following baseline equation (1) with the use of ordinary least squares (OLS):

$$
\begin{aligned}
U D_{i, t+1}= & \alpha_{0}+\alpha_{1} \operatorname{CSRP}_{i, t}+\alpha_{2-n} \text { Control Variable } e_{i, t}+\text { Year } \\
& \text { fixed effect }+ \text { Industry fixed effect }+\varepsilon_{i, t}
\end{aligned}
$$

Subscript i relates to company and t related to the year. The dependent variable UD represents the proportion of unsecured debt, which is expressed by short-term unsecured debt with a maturity date of one year or less (SUD), longterm unsecured debt with a maturity date of more than one year (LUD), and total unsecured debt (TUD) respectively. The above variables are calculated by dividing the amount of different types of unsecured debt by total assets. Also, the amount of different types of unsecured debt is divided by the amount of bank debt corresponding to different debt duration, as a substitute variable for unsecured debt, used in the robustness test; CSRP signifies the firm's CSR performance as graded by Rankins Global. The maximum value of CSRP is set to 100 and the minimum to 0 . The higher the CSRP, the better the CSR performance. Following the findings of Goss and Roberts (2011) and Badoer, Dudley, and James (2020), the control for financial variables that might affect unsecured debt, including firm size (SIZE, the natural logarithm of total assets at the end of the year), leverage (LEV, the ratio of total liabilities over total assets at the end of the year), current ratio (CR, the ratio of current assets over current liabilities at the end of the year), the proportion of fixed assets (FA, the ratio of fixed assets over total assets at the end of the year), cash flow from operating activities (CFO, the ratio of cash flow from operating activities over average total assets), profitability (ROA, the ratio of net income over average total assets), and market to book ratio (MB, the ratio of market value to book value). Together with the actual condition of listed companies in China, we select corporate governance variables, such as dummy variable of state-owned enterprises (SOE, 1 if the actual controller of the company is the state-owned institutions or state-owned enterprises and 0 otherwise), board size (BS, number of board members), proportion of independent director (PID, number of independent directors divided by number of board members) and duality of chairman and CEO (DUAL, 1 if the chairman of the board also assumes the CEO position and 0 otherwise), as control variables. Also, we include year and industry fixed effects in the regression. To control endogeneity problems, all independent variables and control variables are lagged by one-period.

\subsection{Data Sources}

CSR performance data is drawn from Rankins Global; data on unsecured debt are drawn from the notes to the financial statements and the CSMAR database. Data on state-owned enterprises is derived from the WIND database, and the financial and corporate governance data is drawn from the CSMAR database.

\section{Empirical Results}

\subsection{Descriptive Statistics}

Table 1 is a descriptive statistic of the main variables. As the table shows, the average total unsecured debt of 
the sample companies accounted for $7.13 \%$ of total assets. Most of them are short-term unsecured debt, the amount of which is about 2.29 times of long-term unsecured debt, thus implying that long-term unsecured loans bear higher risks for banks. The average score of the CSR performance is 38 points, whereas the full score available is 100 points, indicating that the CSR performance of listed companies is generally insufficient. The average leverage rises to $49 \%$, suggesting that listed companies exhibit high dependence on bank debt financing (See Table 1).

\subsection{Basic Regression Analysis}

Table 2 shows the results of ordinary least squares (OLS) regression using equation (1). The dependent variables in columns (1) to (3) in Table 2 represent short-term unsecured debt (SUD), long-term unsecured debt (LUD) and total unsecured debt (TUD) respectively. The CSR performance (CSRP) coefficient is significantly positive across all three regression models. The results show that companies with good CSR performance can indeed borrow more unsecured debt, including short-term, long-term and total unsecured debt, which verifies hypothesis 1 (See Table 2).

In terms of control variables, the firm size (SIZE) coefficient is not significant in regard to the short-term unsecured debt model, while it is significantly positive for all others. This shows that there is a certain degree of bank credit discrimination against small firms; the leverage
(LEV) coefficient is significantly positive, suggesting that part of a firm's liability is related to unsecured debt; the fixed asset ratio (FA) coefficient is significantly positive, indicating that fixed assets can reduce bank's loan risk. It is worth mentioning that the coefficient of return on assets (ROA) and cash flow from operating activities (CFO) are significantly negative in the short-term and total unsecured debt model. Taking into consideration that total unsecured loans are mainly composed of short-term unsecured loans, it seems that the indicators of ROA and CFO are not significantly important for banks when they decide on shortterm unsecured loans. The SOE coefficient is significantly positive, which suggests that state-owned enterprises are more likely to obtain unsecured debt; the coefficients of board size (BS) and proportion of independent directors (PID) are significantly positive in columns (1) and (3), which shows that corporate governance has a significant impact on unsecured debt.

\subsection{Cross-Sectional Analyses}

We introduce the interaction term CSRP $\times$ SMALLSIZE into the model to determine whether the relation between CSR performance and unsecured debt differs between smaller and larger firms. SMALLSIZE expresses a dummy variable which equals 1 if firm size is smaller than the median size of sample, and is equal to 0 otherwise. Columns (1) to (3) in Table 3 present the regression results (See Table 3).

Table 1: Descriptive statistics

\begin{tabular}{|l|c|c|c|c|c|c|}
\hline Variables & Obs & Min & Max & Mean & Median & SD \\
\hline SUD & 5373 & 0.00000 & 0.30897 & 0.04894 & 0.02079 & 0.06586 \\
\hline LUD & 5373 & 0.00000 & 0.25238 & 0.02144 & 0.00000 & 0.04500 \\
\hline TUD & 5373 & 0.00000 & 0.42329 & 0.07139 & 0.03379 & 0.09112 \\
\hline CSRP & 5373 & 11.69000 & 89.00332 & 38.64376 & 35.98380 & 12.30956 \\
\hline SIZE & 5373 & 20.32027 & 27.03451 & 23.01336 & 22.86485 & 1.42684 \\
\hline LEV & 5373 & 0.06389 & 0.86663 & 0.49245 & 0.50555 & 0.19660 \\
\hline FA & 5373 & 0.00211 & 0.76772 & 0.24790 & 0.20541 & 0.18777 \\
\hline CR & 5373 & 0.22961 & 12.98431 & 1.88039 & 1.39589 & 1.80979 \\
\hline ROA & 5373 & -0.08590 & 0.22643 & 0.04684 & 0.03666 & 0.04987 \\
\hline CFO & 5373 & -0.16672 & 0.27768 & 0.05722 & 0.05504 & 0.07600 \\
\hline MB & 5373 & 0.12199 & 6.24556 & 1.24332 & 0.84113 & 1.16784 \\
\hline SOE & 5373 & 0.00000 & 1.00000 & 0.61493 & 1.00000 & 0.48666 \\
\hline BS & 5373 & 4.00000 & 19.00000 & 9.29518 & 9.00000 & 2.01224 \\
\hline PID & 5373 & 0.09091 & 0.80000 & 0.37384 & 0.36364 & 0.05898 \\
\hline DUAL & 5373 & 0.00000 & 1.00000 & 0.16341 & 0.00000 & 0.36977 \\
\hline
\end{tabular}


Table 2: Regression results of the effect of CSR on unsecured debt

\begin{tabular}{|c|c|c|c|}
\hline \multirow{2}{*}{ Variables } & $\operatorname{SUD}_{\mathrm{i}, \mathrm{t}+1}$ & $\operatorname{LUD}_{\mathrm{i}, \mathrm{t}+1}$ & TUD $_{\mathrm{i}, \mathrm{t}+1}$ \\
\hline & (1) & (2) & (3) \\
\hline \multirow{2}{*}{ CSRP } & $0.00016^{\star *}$ & $0.00014^{* *}$ & $0.00031^{* * *}$ \\
\hline & $(2.00)$ & $(2.48)$ & (3.05) \\
\hline \multirow{2}{*}{ SIZE } & 0.00004 & $0.00781^{* * *}$ & $0.00781^{* * *}$ \\
\hline & $(0.04)$ & (10.62) & $(5.77)$ \\
\hline \multirow{2}{*}{ LEV } & $0.06277^{* * *}$ & $0.03309^{* * *}$ & $0.10203^{* * *}$ \\
\hline & (7.71) & $(6.75)$ & (9.69) \\
\hline \multirow{2}{*}{ FA } & $0.02755^{\star * \star}$ & $0.03430^{* * *}$ & $0.06415^{* * *}$ \\
\hline & $(4.17)$ & $(6.84)$ & (7.19) \\
\hline \multirow{2}{*}{ CR } & $-0.00391^{* * *}$ & $0.00204^{* * *}$ & $-0.00166^{* * *}$ \\
\hline & $(-7.83)$ & (6.09) & $(-2.60)$ \\
\hline \multirow{2}{*}{ ROA } & $-0.10106^{\star * *}$ & -0.01352 & $-0.11662^{* * *}$ \\
\hline & $(-4.86)$ & $(-1.08)$ & $(-4.46)$ \\
\hline \multirow{2}{*}{ CFO } & $-0.04734^{* * *}$ & -0.00824 & $-0.05744^{* * *}$ \\
\hline & $(-3.42)$ & $(-1.18)$ & $(-3.33)$ \\
\hline \multirow{2}{*}{ MB } & $-0.00290^{* *}$ & -0.00002 & -0.00256 \\
\hline & $(-2.39)$ & $(-0.02)$ & $(-1.52)$ \\
\hline \multirow{2}{*}{ SOE } & $0.01440^{* * *}$ & $0.00508^{* * *}$ & $0.02017^{* * *}$ \\
\hline & (7.71) & $(4.74)$ & (8.39) \\
\hline \multirow{2}{*}{ BS } & $0.00165^{\star * *}$ & 0.00055 & $0.00213^{* * *}$ \\
\hline & (3.36) & (1.49) & (3.13) \\
\hline \multirow{2}{*}{ PID } & $0.08628^{* * *}$ & 0.00933 & $0.09743^{* * *}$ \\
\hline & $(5.46)$ & $(1.02)$ & $(4.87)$ \\
\hline \multirow{2}{*}{ DUAL } & $0.00858^{* * *}$ & $-0.00295^{* * *}$ & $0.00599^{* *}$ \\
\hline & (3.58) & $(-2.80)$ & $(2.06)$ \\
\hline \multirow{2}{*}{ _cons } & $-0.03691^{*}$ & $-0.19644^{* * *}$ & $-0.23625^{* * *}$ \\
\hline & $(-1.74)$ & $(-12.61)$ & $(-8.26)$ \\
\hline YEAR & Yes & Yes & Yes \\
\hline IND & Yes & Yes & Yes \\
\hline Adj. $R^{2}$ & 0.20 & 0.31 & 0.29 \\
\hline $\mathrm{N}$ & 5373 & 5373 & 5373 \\
\hline
\end{tabular}

Notes: The values within brackets are t statistics. ${ }^{* * *},{ }^{* *}$, and ${ }^{*}$ denote statistical significance at $1 \%, 5 \%$, and $10 \%$ levels respectively. 
Table 3: Results of cross-sectional analyses

\begin{tabular}{|c|c|c|c|c|c|c|}
\hline \multirow{2}{*}{ Variables } & SUD $_{\mathrm{i}, \mathrm{t}+1}$ & LUD $_{\mathrm{i}, \mathrm{t}+1}$ & TUD $_{i, t+1}$ & SUD ${ }_{i, t+1}$ & LUD $_{\mathrm{i}, \mathrm{t}+1}$ & TUD $_{i, t+1}$ \\
\hline & (1) & (2) & (3) & (4) & (5) & (6) \\
\hline \multirow{2}{*}{ CSRP } & $0.00014^{*}$ & $0.00011^{*}$ & $0.00025^{\star *}$ & $0.00013^{*}$ & $0.00011^{*}$ & $0.00022^{\star *}$ \\
\hline & $(1.71)$ & $(1.78)$ & $(2.35)$ & (1.69) & $(1.76)$ & $(2.15)$ \\
\hline \multirow{2}{*}{ CSRP×SMALLSIZE } & $0.00014^{*}$ & $0.000018^{* *}$ & $0.00015^{* *}$ & & & \\
\hline & $(1.84)$ & $(2.37)$ & $(1.99)$ & & & \\
\hline \multirow{2}{*}{ CSRP×POLLUTION } & & & & $0.00027^{\star \star}$ & $0.00047^{* * *}$ & $0.00063^{* * *}$ \\
\hline & & & & $(2.42)$ & $(5.24)$ & $(4.43)$ \\
\hline \multirow[b]{2}{*}{ _cons } & $-0.04776^{*}$ & $-0.22589^{* * \star}$ & $-0.28223^{* * *}$ & $-0.03589^{*}$ & $-0.20182^{* \star *}$ & $-0.23877^{* \star \star}$ \\
\hline & $(-1.81)$ & $(-10.78)$ & $(-7.86)$ & $(-1.66)$ & $(-12.66)$ & $(-8.19)$ \\
\hline Control Variables & Yes & Yes & Yes & Yes & Yes & Yes \\
\hline YEAR & Yes & Yes & Yes & Yes & Yes & Yes \\
\hline IND & Yes & Yes & Yes & Yes & Yes & Yes \\
\hline Adj. $R^{2}$ & 0.20 & 0.31 & 0.29 & 0.20 & 0.31 & 0.29 \\
\hline $\mathrm{N}$ & 5373 & 5373 & 5373 & 5373 & 5373 & 5373 \\
\hline
\end{tabular}

Notes: The values within brackets are t statistics. ${ }^{* *},{ }^{* *}$, and ${ }^{*}$ denote statistical significance at $1 \%, 5 \%$, and $10 \%$ levels respectively; Due to space limitations, Control variables are not shown in the table.

The dependent variables in columns (1) to (3) in Table 3 represent short-term unsecured debt (SUD), longterm unsecured debt (LUD), and total unsecured debt (TUD) respectively. Consistently with our expectations, the coefficients of CSR $\times$ SMALLSIZE are all significantly positive. The results indicate that the effect of good CSR performance on unsecured debt is more pronounced for small firm. Hence, hypothesis 2 is confirmed.

To test whether heavy-polluting industries can significantly moderate the effect of CSR performance on unsecured debt, we introduce the interaction term CSRP $\times$ POLLUTION into the model. According to the "Guidelines on environmental information disclosure of the listed companies" issued by Ministry of Environmental Protection of the People's Republic of China in 2010, we identified 16 heavy-polluting industries such as thermal power, steel, cement, and electrolytic aluminum and then identified the corresponding 20 China Securities Regulatory Commission (CSRC) three-digit industry codes. POLLUTE is a dummy variable that equals 1 if the firm belongs to heavy-polluting industries, and is equal to 0 otherwise. The regression results are shown in columns (4) to (6) in Table 3.

The coefficients of CSR $\times$ POLLUTION are all significantly positive. This suggests that the effect of CSR performance on unsecured debt is pronounced in cases of firms operating in heavy-polluting industries. Therefore, hypothesis 3 is confirmed. Due to space limitations, Table 3 does not illustrate the coefficients of every industry dummy variables (IND). The reader is reminded that the coefficients of industry dummy variables (IND), belonging to heavypolluting industries, are still significantly negative.

\subsection{Mechanism Analysis}

\subsubsection{CSR and Information Asymmetry}

We use the analyst forecast error to represent a firm's information transparency (Dhaliwal, Radhakrishnan, Tsang, \& Yang, 2012), and explore the relation between CSR performance and information asymmetry in column (1) in Table 4. In the OLS regression, we measure the analyst forecast error (AFERROR), the dependent variable, as the absolute value of the difference between a firm's reported earnings per share and the most recent mean analyst forecast for year $t$, scaled by the beginning-of-year price. The independent variable is CSRP. Following the findings of Dhaliwal et al. (2012), we include control variables, such as the natural logarithm of the number of analysts following the firm (ANANO), the median number of days between analyst forecasts and earnings announcements (FHORIZON), firm size (SIZE), leverage (LEV), market to book Ratio (MB), Tobin Q (TOBINQ), earnings volatility (ROAVOL), earnings of companies which announced accounting losses (LOSS), and corporate governance variables. Accordingly, TOBINQ represents the market value of total assets divided by the book value of total assets; ROAVOL expresses the natural logarithm of the time-series standard deviation of earnings per share over the last five years; LOSS is an indicator variable that equals 1 if the firm reports negative earnings in the year, and 0 otherwise. The results are showed in column (1) in Table 4. 
Table 4: Mechanism Analysis

\begin{tabular}{|c|c|c|c|c|c|c|}
\hline \multirow{3}{*}{ Variable } & \multirow{2}{*}{$\begin{array}{c}\text { OLS Model } \\
\text { AFERROR }_{\mathrm{t}+1}\end{array}$} & \multirow{2}{*}{$\begin{array}{l}\text { Probit Model } \\
\text { VIOLATION }_{\mathrm{t}+1}\end{array}$} & \multicolumn{4}{|c|}{ OLS Model } \\
\hline & & & SUBSIDY $_{\mathrm{t}+1}$ & $\mathrm{IISH}_{\mathrm{t}+1}$ & SBC $_{t+1}$ & $Z_{-} \operatorname{SCORE}_{t+1}$ \\
\hline & (1) & $(2)$ & (3) & (4) & (5) & (6) \\
\hline \multirow{2}{*}{ CSRP } & $-0.00014^{\star *}$ & $-0.00423^{* *}$ & $0.00002^{* \star *}$ & $0.11726^{\star \star \star}$ & $0.00016^{* *}$ & $0.01464^{* * *}$ \\
\hline & $(-2.37)$ & $(-2.08)$ & (3.76) & $(4.44)$ & $(2.10)$ & (3.31) \\
\hline \multirow{2}{*}{ _cons } & $0.01805^{* *}$ & $2.77022^{* \star *}$ & $0.01070^{\star * *}$ & $-8.2 \mathrm{e}+01^{* * *}$ & -0.01762 & $19.60646^{\star * *}$ \\
\hline & $(2.18)$ & $(4.27)$ & (7.81) & $(-11.38)$ & $(-0.93)$ & (14.13) \\
\hline Control Variables & Yes & Yes & Yes & Yes & Yes & Yes \\
\hline YEAR & Yes & Yes & Yes & Yes & Yes & Yes \\
\hline IND & Yes & Yes & Yes & Yes & Yes & Yes \\
\hline Adj.R2/Pseudo $R^{2}$ & Adj. $R^{2}=0.19$ & Pseudo $R^{2}=0.08$ & Adj. $R^{2}=0.18$ & Adj. $R^{2}=0.31$ & Adj. $R^{2}=0.45$ & Adj. $R^{2}=0.64$ \\
\hline$N$ & 4557 & 5373 & 5373 & 5373 & 5373 & 5373 \\
\hline
\end{tabular}

Notes: Values within brackets in column (2) are z statistics, and t statistics in all other columns. ${ }^{* * *}$, ${ }^{* *}$, and * denote statistical significance at $1 \%, 5 \%$, and $10 \%$ levels respectively; Due to the characteristics of analyst forecast, the value of ANANO and FHORIZON are used in period $\mathrm{t}+1$; Due to space limitations, Control variables are not shown in the table.

Column (1) in Table 4 provides strong evidence that CSR performance has a significant negative impact on analyst forecast error. The result reflects the role of CSR performance in reducing information asymmetry between firm's management and external stakeholders.

\subsubsection{CSR and Moral Hazard}

The violation data in the CSMAR database includes various firms' misconducts, such as penalties for accounting methods, information disclosure, contribution and use of capital, insider trading, and financing guarantee. Therefore, this paper takes whether firm has annual violation action as the measure of corporate moral hazard.

Column (2) in Table 4 is result of the Probit regression of the impact of CSR performance on moral hazard. The dependent variable (VIOLATION) is a dummy variable that equals 1 if the firm has a misconduct record in year $t$, and 0 otherwise. The independent variable is CSRP. Following the findings of Liu (2018) and $\mathrm{Li}$ (2019), the control variables include firm size (SIZE), leverage (LEV), profitability (ROA), market to book ratio (MB), Tobin Q (TOBINQ), cash holding $(\mathrm{CASH})$ and corporate governance variables. Accordingly, we measure CASH as cash holdings scaled by total assets. Column (2) in Table 4 shows that the CSRP coefficient is significantly negative, indicating that CSR performance significantly correlates to a firm's misconduct record and behavior. Therefore, we can conclude that good CSR performance has a vital role in reducing the moral hazard of corporate management.

\subsubsection{CSR and the Risk of Default}

This section explores whether firms with good CSR performance can be supported by the government, institutional investors, and suppliers. Columns (3) to (5) in Table 4 illustrate the impact of CSR performance on obtaining the support of the government, shareholders, and suppliers respectively. In accordance to the baseline equation (1) above, we control the same financial and corporate governance variables in columns (3) to (5).

The dependent variable in column (3) in Table 4 represents government subsidies received by firms (SUBSIDY), a government-supported variable which is expressed as the amount of government subsidies divided by total assets. Since government revenue affects government expenditure (Morgan \& Kickham, 1999), we add the proportion of a company's provincial fiscal revenue to provincial GDP (FR) to control variables in column (3). The dependent variable in column (4) represents the shareholding ratio of institutional investors (IISH), a shareholder support variable which is expressed as the proportion of the number of shares held by institutional investors to outstanding shares. Due to the institutional investors' preference of growth opportunities in China (Bai, Liu, Lu, Song, \& Zhang, 2004), we add the Tobin Q (TOBINQ) to the control variable in column (4). The dependent variable in column (5) is the business credit provided by supplier (SBC), a supplier-supported variable expressed as the payable accounts divided by the total assets.

Columns (3) to (5) in Table 4 illustrate that the CSRP coefficients are all significantly positive. We observe that firms with good CSR performance can obtain more 
government support, attract more institutional investors, and acquire more credit from suppliers.

Furthermore, this paper also examines the relationship between CSR performance and the risk of bankruptcy directly. For the purpose of this paper, we use the $\mathrm{Z}$ score (Z SCORE) of Altman (1968) as the proxy variable for risk of bankruptcy. The regression results of the impact of CSR performance on the risk of default and bankruptcy are presented in column (6) in Table 4. The CSRP coefficient is significantly positive in column (6), which indicates that CSR performance has a significantly positive impact on reducing bankruptcy risk, which helps reduce corporate risk of default.

\subsection{Additional Analysis}

To determine whether good CSR performance can substitute collateral as an indicator of a firm's creditworthiness, and to observe the borrowers' preference for different types of bank debt, we use the ratio of secured debt as a dependent variable to re-estimate OLS regression. The results are shown in Table 5.

Column (1) of Table 5 illustrates the regression result of the impact of CSR performance on short-term secured debt. The dependent variable, SSD, represents the ratio of shortterm secured debt and is measured as the amount of shortterm unsecured debt, scaled by total assets. The dependent variable in column (2), LSD, represents the ratio of longterm secured debt and is expressed as the amount of longterm unsecured debt, scaled by total assets. Accordingly, the dependent variable in column (3), TSD, expresses the ratio of total secured debt, which is defined similarly. The coefficients of CSRP are all significantly negative, indicating that firms with good CSR performance do not have a preference for secured debt. Compared to the effect of CSR on unsecured debt, we conclude that good CSR performance can substitute collateral as an indicator of a firm's creditworthiness and reduce the banks' credit risk. This is also consistent with the results of Benmelech et al. (2020) that firms with low risk prefer unsecured debt.

\section{Conclusions}

Based on the theoretical analysis of the main factors influencing the banks' decision-making process in regard to credit loan, this paper examines listed companies in China between 2009 and 2018 as a case-study to evaluate the impact of CSR performance on unsecured debt. It outlines the mechanism of the reduction of information asymmetry, moral hazard and the risk of default and bankruptcy, and considers the different effects of CSR performance on unsecured debt depending on firm size and the characteristics of the respective industry. We find that companies with good CSR performance can borrow more unsecured debt, including short-term, long-term, and total unsecured debt. The reason is that good CSR performance reduces information asymmetry, constrains the moral hazard of the management, and reduces the risk of default and bankruptcy, thereby reducing the risk of unsecured loans.

Furthermore, the effect of CSR performance on unsecured debt is more pronounced for small firms and those operating in heavy-polluting industries. One of the reasons is that CSR performance has more incremental information and value on the decision-making processes of small firms, which have more information asymmetry than bigger enterprises. Another reason is that CSR performance can enhance legitimacy more effectively in heavy-polluting industries, which helps decrease a firm's default risk.

Table 5: Regression results of the effect of CSR on secured debt

\begin{tabular}{|l|c|c|c|}
\hline \multirow{2}{*}{ Variables } & SSD $_{t+1}$ & LSD $_{t+1}$ & TSD $_{t+1}$ \\
\cline { 2 - 4 } & $\mathbf{( 1 )}$ & $\mathbf{( 2 )}$ & $\mathbf{( 3 )}$ \\
\hline \multirow{2}{*}{ CSRP } & $-0.00035^{\star * *}$ & $-0.00015^{*}$ & $-0.00039^{* * *}$ \\
\cline { 2 - 4 } & $(-5.18)$ & $(-1.83)$ & $(-3.53)$ \\
\hline \multirow{2}{*}{ Cons } & $0.32498^{* \star *}$ & $0.11798^{* * *}$ & $0.44795^{* * *}$ \\
\hline YEAR & $(15.63)$ & $(4.68)$ & $(13.66)$ \\
\hline IND & Yes & Yes & Yes \\
\hline Adj.R $R^{2}$ & Yes & Yes & Yes \\
\hline $\mathrm{N}$ & Yes & Yes & Yes \\
\hline
\end{tabular}

Notes: Values within brackets are t statistics. ${ }^{* * *},{ }^{* *}$, and ${ }^{*}$ denote statistical significance at $1 \%, 5 \%$, and $10 \%$ levels respectively; Due to space limitations, Control variables are not shown in the table. 
Additionally, this paper documents that firms with good CSR performance have a preference for unsecured debt, but decline to provide collateral for debt. Arguably, good CSR performance can function as an effective indicator of a firm's creditworthiness effectively to banks. Since CSR performance can help reduce information asymmetry, moral hazard, and risk of default and bankruptcy, and thus reduce the bank's credit risk, banks should evaluate the borrower's CSR performance, identify the borrower's risk, and control the ex post credit risk to promote the efficiency of credit resource allocation and the fulfillment of the CSR in the real economy. Furthermore, banks can use CSR information to reduce information asymmetry between borrowers and lenders, improve information screening and analysis, and thus enhance the competitiveness within the credit business.

\section{References}

Albuquerque, R., Koskinen, Y., \& Zhang, C. (2019). Corporate social responsibility and firm risk: Theory and empirical evidence. Management Science, 65(10), 4451-4469.

Almeida, H., Campello, M., \& Weisbach, M. S. (2004). The cash flow sensitivity of cash. Journal of Finance, 59(4), 1777-1804.

Altman, E. I. (1968). Financial ratios, discriminant analysis and the prediction of corporate bankruptcy. The Journal of Finance, 23(4), 589-609.

Arnoud, W. A. B., Thakor, A. V., \& Udell, G. F. (1991). Secured Lending and Default Risk: Equilibrium Analysis, Policy Implications and Empirical Results. The Economic Journal, 101(406), 458-472.

Attig, N., El Ghoul, S., Guedhami, O., \& Suh, J. (2013). Corporate social responsibility and credit ratings. Journal of Business Ethics, 117(4), 679-694.

Badoer, D. C., Dudley, E., \& James, C. M. (2020). Priority spreading of corporate debt. The Review of Financial Studies, 33(1), 261-308.

Bai, C. E., Liu, Q., Lu, J., Song, F. M., \& Zhang, J. (2004). Corporate governance and market valuation in China. Journal of Comparative Economics, 32(4), 599-616.

Barnea, A., \& Rubin, A. (2010). Corporate social responsibility as a conflict between shareholders. Journal of Business Ethics, 97(1), 71-86.

Benlemlih, M. (2017). Corporate Social Responsibility and Firm Debt Maturity. Journal of Business Ethics, 144(3), 491-517.

Benmelech, E., \& Bergman, N. K. (2009). Collateral pricing. Journal of Financial Economics, 91(3), 339-360.

Benmelech, E., Kumar, N., \& Rajan, R. (2020). The decline of secured debt (0898-2937). Retrieved from https://corpgov.law. harvard.edu/2020/01/27/the-decline-in-secured-debt/

Berger, A. N., Frame, W. S., \& Ioannidou, V. (2016). Reexamining the empirical relation between loan risk and collateral: The roles of collateral liquidity and types. Journal of Financial Intermediation, 26, 28-46.

Brickson, S. L. (2007). Organizational identity orientation: The genesis of the role of the firm and distinct forms of social value. Academy of Management Review, 32(3), 864-888.

Brown, S., \& Hillegeist, S. A. (2007). How disclosure quality affects the level of information asymmetry. Review of Accounting Studies, 12(2-3), 443-477.

Bushman, R. M., Piotroski, J. D., \& Smith, A. J. (2004). What determines corporate transparency? Journal of Accounting Research, 42(2), 207-252.

Cahan, S. F., Chen, C., Chen, L., \& Nguyen, N. H. (2015). Corporate social responsibility and media coverage. Journal of Banking \& Finance, 59, 409-422.

Cai, L., Cui, J., \& Jo, H. (2016). Corporate environmental responsibility and firm risk. Journal of Business Ethics, 139(3), 563-594.

Chan, Y.-S., \& Kanatas, G. (1985). Asymmetric valuations and the role of collateral in loan agreements. Journal of Money, Credit and Banking, 17(1), 84-95.

Collins, M., \& Baker, M. (2005). English bank business loans, 1920-1968: Transaction bank characteristics and small firm discrimination. Financial History Review, 12(2), 135-171.

Dbouk, W., Jin, D., Wang, H., \& Wang, J. (2018). Corporate Social Responsibility and Rule 144A Debt Offerings: Empirical Evidence. International Journal of Financial Studies, 6(4), 94. https://doi.org/10.3390/ijfs6040094

Degryse, H., Karapetyan, A., \& Karmakar, S. (2018). To Ask or Not To Ask? Bank Capital Requirements and Loan Collateralization. Working paper, Available at SSRN: https:// ssrn.com/abstract $=3290523$.

Dhaliwal, D. S., Radhakrishnan, S., Tsang, A., \& Yang, Y. G. (2012). Nonfinancial Disclosure and Analyst Forecast Accuracy: International Evidence on Corporate Social Responsibility Disclosure. Accounting Review, 87(3), 723-759.

Diamond, D. W. (1991). Monitoring and reputation: The choice between bank loans and directly placed debt. Journal of Political Economy, 99(4), 689-721.

Diamond, D. W., \& Verrecchia, R. E. (1991). Disclosure, liquidity, and the cost of capital. The Journal of Finance, 46(4), 13251359.

Fort, T. C., Haltiwanger, J., Jarmin, R. S., \& Miranda, J. (2013). How firms respond to business cycles: The role of firm age and firm size. IMF Economic Review, 61(3), 520-559.

Ge, W., \& Liu, M. (2015). Corporate social responsibility and the cost of corporate bonds. Journal of Accounting and Public Policy, 34(6), 597-624.

Ge, W. X., Kim, J. B., \& Song, B. Y. (2012). Internal governance, legal institutions and bank loan contracting around the world. Journal of Corporate Finance, 18(3), 413-432. 
Xia CHEN, Zhe MA, Jiayu SHI, Bingyan TU, Songtao XU I

Gonas, J. S., Highfield, M. J., \& Mullineaux, D. J. (2004). When are commercial loans secured? Financial Review, 39(1), 79-99.

Goss, A., \& Roberts, G. S. (2011). The impact of corporate social responsibility on the cost of bank loans. Journal of Banking \& Finance, 35(7), 1794-1810.

Holmstrom, B. (1979). Moral hazard and observability. Bell Journal of Economics, 10(1), 74-91.

Jo, H., \& Na, H. (2012). Does CSR reduce firm risk? Evidence from controversial industry sectors. Journal of Business Ethics, 110(4), 441-456.

Kim, Y., Park, M. S., \& Wier, B. (2012). Is Earnings Quality Associated with Corporate Social Responsibility? Accounting Review, 87(3), 761-796.

Kölbel, J. F., \& Busch, T. (2020). Signaling legitimacy across institutional contexts: The intermediary role of corporate social responsibility rating agencies. Global Strategy Journal. doi:10.1002/gsj.1355

Lee, J. W. (2020). CSR Impact on the Firm Market Value: Evidence from Tour and Travel Companies Listed on Chinese Stock Markets. Journal of Asian Finance, Economics and Business, 7(7), 159-167. https://doi.org/10.13106/jafeb.2020.vol7. no7.159

Li, M. (2019). Moral Hazard and Internal Discipline: Theory and Evidence. The Accounting Review, 94(4), 365-400.

Lins, K. V., Servaes, H., \& Tamayo, A. (2019). Social capital, trust, and corporate performance: How CSR helped companies during the financial crisis (and why it can keep helping them). Journal of Applied Corporate Finance, 31(2), 59-71.

Lins, K. V., Servaes, H., \& Tamayo, A. N. E. (2017). Social Capital, Trust, and Firm Performance: The Value of Corporate Social Responsibility during the Financial Crisis. The Journal of Finance, 72(4), 1785-1824.

Liu, C. (2018). Are women greener? Corporate gender diversity and environmental violations. Journal of Corporate Finance, $52,118-142$.

Luk, P., \& Zheng, T. (2018). Dynamics of secured and unsecured debt over the business cycle. Retrieved from https://www.imfs-
frankfurt.de/fileadmin/user_upload/Events_2018/MMCI_ Conference/Papers/01-Paul_Luk-Dynamics_of_Secured_and Unsecured_Debt_Over_the_Business_Cycle.pdf

Manove, M., Padilla, A. J., \& Pagano, M. (2001). Collateral versus project screening: A model of lazy banks. Rand Journal of Economics, 32(4), 726-744.

Morgan, D. R., \& Kickham, K. (1999). Changing the form of county government: Effects on revenue and expenditure policy. Public Administration Review, 59(4), 315-324.

Nguyen, S. L., Pham, C. D., Nguyen, A. H., \& Dinh, H. T. (2020). Impact of Corporate Social Responsibility Disclosures on Bankruptcy Risk of Vietnamese Firms. Journal of Asian Finance, Economics and Business, 7(5), 81-90. https://doi. org/10.13106/jafeb.2020.vol7.no5.081

Oikonomou, I., Brooks, C., \& Pavelin, S. (2014). The effects of corporate social performance on the cost of corporate debt and credit ratings. Financial Review, 49(1), 49-75.

Pedersen, E. R. (2006). Making corporate social responsibility (CSR) operable: How companies translate stakeholder dialogue into practice. Business and Society Review, 111(2), 137-163.

Pellegrino, C., \& Lodhia, S. (2012). Climate change accounting and the Australian mining industry: Exploring the links between corporate disclosure and the generation of legitimacy. Journal of Cleaner Production, 36, 68-82.

Rauh, J. D., \& Sufi, A. (2010). Capital Structure and Debt Structure. Review of Financial Studies, 23(12), 4242-4280.

Russo, A., \& Perrini, F. (2010). Investigating stakeholder theory and social capital: CSR in large firms and SMEs. Journal of Business Ethics, 91(2), 207-221.

Verrecchia, R. E. (2001). Essays on disclosure. Journal of Accounting and Economics, 32(1-3), 97-180.

Yoon, B., \& Lee, J.-H. (2019). Corporate Social Responsibility and Information Asymmetry in the Korean Market: Implications of Chaebol Affiliates. Journal of Asian Finance, Economics and Business, 6(1), 21-31. http://doi.org/10.13106/jafeb.2019.vol6. no1.21 